\title{
Review report on the role of bioproducts, biopreparations, biostimulants and microbial inoculants in organic production of fruit
}

\author{
Michał Pylak (D) Karolina Oszust (D) Magdalena Frąc $(\mathbb{D}$
}

Published online: 15 July 2019

(C) The Author(s) 2019

\begin{abstract}
The demand for ecologically cultivated fruits is growing each year, but the yields in organic farming are still lower than the yields in conventional farming. Moreover plant pathogens are a serious threat in organic fruit production and the assortment of conventional pesticides is limited in organic farming. The European Commission has established regulations that state which types of bioproducts can be used in organic farming. Appropriately chosen biopreparations might be a solution to this problem. Biopreparations are products used to inhibit the growth of pathogenic fungi or bacteria, stimulate plants growth and enhance plant nutrient uptake. They can be composed of plant growth promoting bacteria and fungi, plant extracts or animals-derived compounds. The second category of bioproducts useful for enhancing yield and nutrient uptake are biostimulants. They can be composed of microorganisms, protein hydrolysates, seaweed extracts and other substances. Bacteria, fungi and yeasts are used in biocontrol of plant pathogens and in enhancing plants growth by producing hormone-like substances and reducing symptoms of environmental stress caused by weather or soil factors such as drought or low nutrient availability.
\end{abstract}

M. Pylak $\cdot$ K. Oszust $(\bowtie) \cdot$ M. Frąc Institute of Agrophysics, Polish Academy of Sciences, Doświadczalna 4, 20-290 Lublin, Poland e-mail: k.oszust@ipan.lublin.pl
Keywords Strawberries $\cdot$ Horticulture $\cdot$ Plant pathogens $\cdot$ Nutrients availability $\cdot$ Plant growth promoting fungi $\cdot$ Plant growth promoting rhizobacteria

\section{Introduction}

It is hard to deny that organic farming is one of the most important practices in fruits production, in the context of modern agriculture (Barłowska et al. 2017). Approximately a third part of the world's organic farming is located in Europe, and 6.4\% of European organic farming is currently in Poland. The area of organic cultivation has increased over recent years significantly. The fastest growth of organic farming was observed between 1999 and 2013. Throughout this period, the number of organic food producers in Poland rose from 27 to 26499 , and the cultivated area increased from 300 to 674694 ha (Kiełbasa 2015). Increased demand for organic fruits has been observed in the past years. The total area under organic cultivation in the EU-28 has risen from just over 4 million ha in 2002, to 12 million ha in 2016 (McEldowney 2018). It is important to know that when farmers decide to cultivate an area by means of the organic method, they are obliged not to use most of the commercially available pesticides. Because of this fact, the costs of organic food production are higher, 
and the yield is usually lower comparing to the conventional farming (Kiełbasa 2015). Organic agriculture very often is considered as a system oriented towards revitalization of soil as a self-regulatory mechanism in case of respecting the main agronomic and ecological regularities. In such a system application of external inputs, even of biological origin, should be limited and before application each biopreparation or solution should be tested comprehensively. Therefore, this restriction also stimulated the scientific research in terms of biological methods of plant protection and biostimulation. European Commission regulations state that bioproducts such as Azadirachtin extracted from Azadirachta indica (Neem tree), lecithin with fungicidal properties, plant essential oils or microorganism-based biopreparations are allowed in organic production of fruits (appendix to WE No. 889/2008). WE No. 834/2007 states that using chemical pesticides must be limited to the absolute minimum and farmers are encouraged to use substances of natural origin. During past years of research many different types of products were invented including: bioproducts, biopreparations, biostimulants and microbial inoculants, to enhance plants health, vigor, growth and yield or/and protect them against abiotic and biotic stress factors including plant pathogens.

Biopreparations is any product derived from a living organism or its metabolites. Bioproducts or biobased products are materials, chemicals, and energy from renewable biological resources (Singh et al. 2003). Biostimulants are materials, other than fertilizers, that promote plant growth when applied in low quantities (du Jardin 2015). Microbial inoculants are amendments containing beneficial microorganisms, able to promote plants health.

Biopreparations are products used to inhibit the growth of pathogenic fungi or bacteria. They can be made from a variety of bioproducts obtained from natural sources. This includes plant extracts, humic substances, polysaccharides, e.g. chitosan. Biopreparations can also contain a great variety of beneficial microorganisms, bacteria or fungi. It has been found that in many cases they may be at least as efficient in biocontrol of fruit pathogens as conventional, commercially available products (Wagner and Hetman 2016). It is important to remember, that the efficacy of biopreparations varies and is highly dependent on many factors such as soil and air humidity or rainfalls
(Pačuta et al. 2018). Storage conditions can also influence the germination rates of conidia in biopreparations based on fungi like Trichoderma harzianum (Leal et al. 2016). Also, it should be borne in mind that different species of the pathogen genus may not be sensitive to identical biopreparation to the same extent (Hussein et al. 2014).

The aim of this review is to characterize various commercially available biopreparations and bioproducts based on plant growth promoting bacteria and fungi, plant and algae extracts, and animals-derived bioproducts such as chitosan. Furthermore, as the review characterize biostimulants and their performance, as well as overviews most common microbial inoculants used for plant pathogens biocontrol and the enhancement plants growth. The scheme summarizing the content of this reviews is given at Fig. 1.

\section{Biostimulants}

Organic horticulture aims to reduce impact of fruit production on ecosystems. However, it generates lower yields and more land is needed compering to conventional one (Dorais and Alsanius 2015). Substances other than fertilizers, that have the ability to promote plant growth even when applied in low quantities e.g. Kelpak Sl are defined as biostimulants (du Jardin 2015). Application of biostimulants is intended to increase crop productivity in organic farming more widely (Trewavas 2001). Yield in organic farming may be lower by $5-32 \%$ in comparison to conventional farming practices, depending on the plants tested (Ponisio et al. 2015). Many factors contribute to the situation and previous research suggests it might be associated with fungal or bacterial pathogens and nutrient limitations (De Ponti et al. 2012). Some of the studies have shown that the nutrient availability (mostly $\mathrm{N}$ and $\mathrm{P}$ ) is the main cause of lower yield in organic horticulture (Berry et al. 2002). Commonly used organic fertilizers are mostly: pelleted chicken manure, fish and meat meal, seabird and bat guano and abattoir waste. Due to their characteristics they fail to supply plants with the most needed nutrients during the intense growing period (Tuomisto et al. 2012; Zhao et al. 2009). Another factor that needs to be taken under consideration is bioavailability of other nutrients e.g. $\mathrm{Fe}, \mathrm{P}, \mathrm{Zn}, \mathrm{Cu}$, $\mathrm{Mn}$. The uptake of these elements is often reduced in 
Fig. 1 Presentation of biopreparations, biostimulants and microbial inoculants

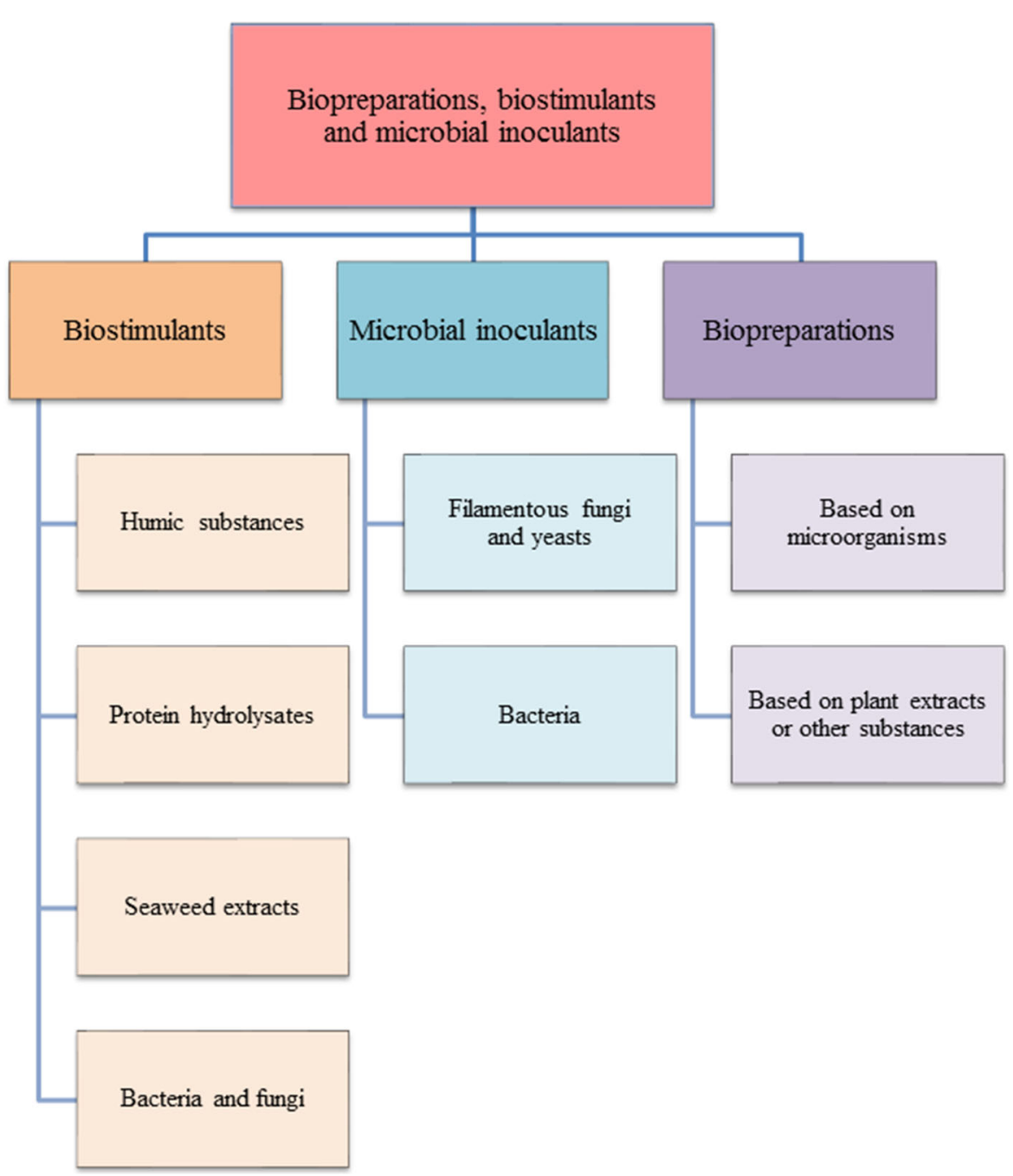

unfavourable soil $\mathrm{pH}$, which means these elements form insoluble compounds in alkaline or acidic soils (Barbieri et al. 2015). Du Jardin (2015) defined plant biostimulants (PBs) as any substance or microorganisms supplied to plants primarily with the aim of enhancing nutrition uptake efficiency, but also increasing abiotic stress tolerance and/or crop quality traits, regardless of its nutrients content. The most promising PBs are: seaweed extracts, protein hydrolysates, humic and fulvic acids, silicon, chitosan, inorganic compounds and beneficial fungi and bacteria (Ruzzi and Aroca 2015).

The enhancement of the nutrient uptake and assimilation is one of the benefits of using biostimulants. It is often attributed to at least one of the following factors: biostimulants can increase the activity of soil both microbiologically and enzymatically, they are able to affect the root structure, and change the solubility and transportability of micronutrients (Colla and Rouphael 2015; Ertani et al. 2009; Lucini et al. 2015). In the past few decades not only the use of biostimulants in organic horticulture was under research, but also the use of microbial inoculum. Plant growth promoting bacteria and fungi might be essential for maintaining proper growth, despite nutrient limitation commonly occurring in organic farming (Rouphael et al. 2017). They can be combined with $\mathrm{Si}$ to enhance their ability to alleviate biotic stress (Etesami 2018). Nutrient uptake facilitated by microorganisms resulting in better plant growth, is a result of diverse mechanisms such as: supplying nitrogen to soil by biological fixation of $\mathrm{N}_{2}$; enhancing 
bioavailability of soil nutrients by secreting enzymes (i.e. phosphatases), the presence of siderophores or organic acids that have the ability of mineral phosphates solubilisation and other nutrients; increasing the surface contact between roots and soil and consequently increasing plant's access to nutrients (Calvo et al. 2014; Colla et al. 2015a; Rouphael et al. 2015).

\subsection{Nutrient availability in soil}

It is common for plants in organic farming to experience nutrient deficiencies due to the low amounts of soil nutrients or their low solubility. One of the roles of plant biostimulants is increasing the amount of nutrients available for plants by increasing soil cation exchange via providing nitrogen and enhancing solubility of soil nutrients (De Pascale et al. 2017).

Some of the most important plant biostimulants commonly used for many years are humic substances. They are formed as the result of the chemical and biological decomposition of organic matter, including microbiological processes (du Jardin 2015). Humic substances are recognized as an indispensable part of physico-chemical soil properties. They stimulate root growth and thus increase soil nutrient availability due to an increase in the area contact between soil and roots (Canellas et al. 2015). Humic compounds are capable of increasing soil cation exchange capacity and neutralize soil $\mathrm{pH}$. They also create complexes with insoluble elements like $\mathrm{Fe}$ and make them available for plants. This is an important property, because it allows to supply plants in micronutrients, which are not easily available (García-Mina et al. 2004). Fulvic acids, which are a part of humus substances can be absorbed by a plant as a complex with cations, because of their small molecular mass. It is also confirmed that humic substances have the ability to inctease plasma membrane $\mathrm{H}^{+}$-ATPase activity, enhancing $\mathrm{H}^{+}$secretion which lowers the $\mathrm{pH}$ of soil and root surface. Lower $\mathrm{pH}$ assists with nutrient availability and uptake (Canellas et al. 2015; Nardi et al. 2002). Humic substances have also the ability to impact stress reduction and the production of secondary metabolites. Humic and fulvic acids can bind heavy metals, therefore there are less likely to be assimilated by the plant during nutrient uptake (Yang et al. 2013). The $\mathrm{Pb}^{2+}$ is a toxic lead ion often found in lead polluted soils. It can be complexed by humic compounds, so that it becomes less soluble and its uptake is reduced. Depending on soil $\mathrm{pH}$ the efficiency of this process might vary and it was observed, that humic substances are not particularly effective in reducing the solubility of heavy metals in acidic soils $(\mathrm{pH}<5)$ (Park et al. 2013; Yang et al. 2013).

Protein hydrolysates $(\mathrm{PH})$ are another principal group of plant biostimulants. There are a mixture of oligopeptides, polypeptides and amino acids that are being made out of protein used partial hydrolysis (Schaafsma 2009). They can be applied as foliar sprays or dosed into the soil near the plant's roots (Colla et al. 2015b). They not only enhance soil properties like respiration but also act as growth stimulants for soil microbiota due to their ability to use the $\mathrm{PH}$ are an easy carbon and nitrogen sources readily available sources for microorganisms. Protein hydrolysates can also complex and chelate soil micro- and macronutrients so that these become more accessible to plants (du Jardin 2015; Farrell et al. 2014).

Another important category of plant biostimulants are bacteria and fungi that have the ability to promote plants growth. There are many species that are symbiotic to plants e.g. Azorhizobium, Allorhizobium, Bradyrhizobium, Mezorhizobium, Rhizobium, and Sinorhizobium and non-symbiotic nitrogen-fixing bacteria like Azospirillum, Azotobacter, Bacillus and Klebsiella (Bhardwaj et al. 2014; Calvo et al. 2014; Hayat et al. 2010; Miransari 2011). They are used to enhance plants growth by increasing the amount of nitrogen, phosphorus and other micronutrients in soil. The usefulness of those bacteria goes beyond fixing the $\mathrm{N}_{2}$, they also have the ability to recycle organic matter. The biostimulants can mineralize organic nitrogen through nitrite to nitrate that is easily absorbed by plants (Miransari 2011). One of the most important and well-studied nitrogen binding bacteria species is Azospirillum spp. (Calvo et al. 2014). An increased soil nitrogen content was observed after inoculating sugarcanes plantation with $A$. dizaotrophicus, with an increase of up to 60-80\% compared to conventional agriculture (Boddey et al. 1991). Furthermore, some Bacillus species i.e. B. megaterium, $B$. circulans, $B$. subtilis, B. polymyxa, B. sircalmous have the ability to solubilise phosphates. The mechanisms of plant growth promoting by bacteria and fungi are complex, and still not fully understood (Satyaprakash et al. 2017). Some of them are capable of producing 
plant hormones for instance auxins, cykokinins, gibberellins, ethylene and abscisic acid (Hayat et al. 2010). Auxins are well known for their capacity to stimulate root growth and in consequence nutrient and water uptake. Cykokinins are responsible for intensifying mitotic cell division in shoots and roots. Gibberellins affect flower and fruit formation, as well as seed germination. Finally, abscisic acid plays an important role in responses to draught, high salinity, and other environmental stresses (Sah et al. 2016). Some strains of bacteria are also able to produce phosphatases and organic acids which are essential to solubilise inorganic phosphate. This leads to increasing concentration of phosphate in soil so that it is more readily available for plants. Mycorrhizal fungi are also responsible for enhancing plants growth in organic farming. They have the ability to live in a symbiosis with plants-hyphae growing into plants roots increase their surface area resulting in increased capacity for absorbing nutrients and water. Fungi also produce siderophores, which chelates iron ions, and secrete phosphatase, and other organic compounds which are essential to enhancing $\mathrm{P}$ availability (Rouphael et al. 2015).

\subsection{Uptake of nutrients by plants}

The ability to uptake nutrients depends on many factors like e.g. environmental conditions, plant species, development of root system, and microorganisms living in symbiosis with roots. The development of roots plays a fundamental role in plants ability to effectively absorb nutrients specially in organic horticulture, where nutrients may appear in soil in low concentrations (De Pascale et al. 2017). It was proved that plant biostimulants enhance the root growth leading to larger root surface area and soil penetration, but recent studies suggest, that the auxins concentration in many biostimulants is too low to efficiently stimulate root grow (Wally et al. 2013). It was observed, that organic compounds, like amino acids, aromatic carboxylic acids and linear carboxylic acids found in humic acids can act as auxins to the plant stimulating the root growth. Moreover, humic substances are capable of stimulate the expression of genes instrumental in responding to presence of auxins, and enhancing the synthesis of plasma membrane $\mathrm{H}^{+}$-ATPase, which stimulates root growth.
Protein hydrolysates also play an important role in stimulating plant's roots growth and have been proven to do so not only in crops like tomatoes or lettuce but also in fruits like strawberries (Lucini et al. 2015; Marfà et al. 2009). This property is thought to be the effect of peptides and amino acids capable of acting as signalling molecules like hormones (Matsubayashi and Sakagami 2006). Many studies have been conducted over the years showing that, for example tryptophan can be linked to inducing auxins production in plants fertilized with biostimulants, glutamate might be a key to the change roots architecture. It has the ability to stimulate the root branching, which advances plants ability to exploit the soil (Colla et al. 2014; Forde and Lea 2007). Moreover, biostimulants also intensify the growth of bacteria and fungi, which might have the ability to produce auxins-like substances (Luziatelli et al. 2016).

Some research reported enhanced growth of the plant roots cultivated with the addition of seaweed extract (SWE). It is a complex mixture composed of polysaccharide, fatty acids, vitamins, phytohormones and mineral nutrients (Battacharyya et al. 2015). It has been found, that addition of SWE can increase the root biomass in hydroponically grown plants even with low nutrient concentration in the medium (Vernieri et al. 2006). The authors of a publication from 2014 have proved that the foliar application of seaweed extract three times in concentration of $2 \mathrm{ml} \mathrm{l}^{-1}$ have induced positive effects on the plant growth, fruit yield, and quality of Sweet Charlie strawberry plants produced from cold stored transplants (Youssef and Metwally 2014). Other researchers have found out that fertilising strawberry plants with Ascophyllum extract in form of solution weekly added to the soil, increased total root length, root surface area, root volume per plant, leaf area and shoot fresh/dry weights of strawberry. The soil microbial colony counts and total microbial physiological activity in soil were also increased (Alam et al. 2013).

Biostimulants based on microorganisms are also capable of enhancing plants root growth, for instance Trichoderma spp. can promote plants root growth, by secreting auxin-like compounds in its hyphae, or enhancing auxin production in mycorrized plant roots (Colla et al. 2015a; Frąc et al. 2018). A meta-analysis conducted by Rubin et al. (2017) showed, that bacteria promoting root growth in plants may increase root mass up to $35 \%$ in well-watered conditions and up to 
$43 \%$ in drought conditions. Endophytic fungi and plant growth promoting bacteria enhances root growth, in combination with external mycorrhizal mycelium enlarge the volume of soil available for plant nutrient uptake, and it enhances resilience with respect to low nutrient concentration in soil.

The usefulness of biostimulants in enhancing the nutrient uptake in plants consists not only in enhancing root growth, but also on increasing the nutrient uptake itself. Some studies suggest, that biostimulators such as humic substances, protein hydrolysates or seaweed extracts are up-regulating genes involved in nutrients transport. For example it has been proven, that humic acids can up-regulate genes (BnNRT1.1 and BnNRT2.1) responsible for nitrogen transport in Brassica napus (Jannin et al. 2012). A similar property was observed by Cerdán et al. (2013). The authors reported, that root application of protein hydrolysates, extracted from plants, can enhance plants Fe(III)chelate reductase activity. This results in increased the capacity to uptake iron ions from the soil. It has also been found that inoculating soil with arbuscular mycorrhizal fungi (AMF) (e.g. Scutellospora calospora, Acaulospora laevis, Gigaspora margarita, Glomus aggregatum, Rhizophagus irregulare (syn $G$. intraradices), Funneliformis mosseae (syn G. mosseae), G. fasciculatum, G. etunicatum, and G. Deserticola) and/or plant growth-promoting rhizobacteria (PGPR) (e.g. Bacillus amyloliquefaciens, B. brevis, $B$. circulans, B. coagulans, B. firmus, B. halodenitrificans, B. laterosporus, B. licheniformis, B. megaterium, B. mycoides, B. pasteurii, B. polymyxa, and $B$. subtilis) up-regulate the genes responsible for nitrate transport (NRT1.1, NRT2, and NAR2.2), which resulted in enhancing nitrogen uptake and increasing the overall nitrogen in durum wheat biomass (Saia et al. 2015). Studies also show, that root inoculation of potted pear plants with Staphylococcus and Pantoea lead to increased $\mathrm{Fe}$ absorption from soil. It is suspected to be the effect of lowering $\mathrm{pH}$ value of rhizosphere and the resulting increase in the activity of root $\mathrm{Fe}(\mathrm{III})$-chelate reductase.

\subsection{Assimilation of nutrient by plants}

The least studied property of plant biostimulants is their capacity to stimulate expression of genes responsible for enzymes important in plants' metabolism and in assimilation of absorbed nutrients. From over 30,000 genes analyzed 300 genes were expressed in a different way in plants treated with humic substances 3 days before the analysis, compare to non-treated plants. A month later still over a 100 genes were being expressed differently. 50\% of upregulated genes under investigation were taking part in nitrogen assimilation or in photosynthesis (Jannin et al. 2012). Similar research conducted on protein hydrolysates has shown, that this type of biostimulants can enhance enzymes activity, in particular enzymes responsible for carbon metabolism, and nitrate assimilation (Schiavon et al. 2008). Related studies were conducted on seaweed extracts, and the results proved that the seaweed extract applied by a foliar spray also has the ability to stimulate nitrogen assimilation enzymes (Zhang et al. 2010). Such experiments were prepared using microorganisms. Plants inoculation with arbuscular mycorrhizal fungi Glomus intraradices or plant growth-promoting rhizobacteria Pseudomonas mendocina enhanced the activity of nitrate reductase in leaves (Kohler et al. 2008).

\section{Microbial inoculants}

While discussing bioproducts and biopreparations it is important to take a closer look at microorganisms included the products. Organisms used in commercially available bioproducts are mostly plant growth promoting fungi and bacteria. They are able to enhance nutrient uptake by plants, to parasite on plant pathogens, to induce resistance of plants, or to secrete hormone-like compounds.

\subsection{Fungi and yeasts}

Fungi and yeasts presented in this section are some of the most commonly used species in the current research, and currently available biopreparations.

\subsubsection{Trichoderma spp.}

One of the most effective antagonists of plant pathogens are the fungi belonging to Trichoderma genus. Trichoderma harzianum, as a compound of some biopreparations is one of the most commonly used plant pathogen antagonist. It not only has the capacity to function as a mycoparasite, but it also produces antibiotic substances and due to high grow 
rate it is an excellent nutrient competitor. Morover, it can also stimulate plant defense mechanisms (Benítez et al. 2004). Biopreparations with Trichoderma harzianum are used in many countries e.g. in Poland, and marketed as a Trianum-P with the T-22 strain. Many scientist have studied the production of antimicrobial compounds by Trichoderma sp. and they have found out that the fungi are capable of producing, among other things, viriden, peptaboils, gliotoxines, sesquiterpenes and isonitryles. Those compounds are toxic enzymes that are being used by the fungi to inhibit the growth of other competitors in the ecological niche (Berg et al. 2004). Due to the capacity to produce chitinase the fungi belonging to Trichoderma can act as a mycoparasite through the degradation of pathogen cell walls (Benítez et al. 2004; El-Katatny et al. 2000; Kubicek et al. 2001; Larkin 2016; Ozbay and Newman 2004). The spectrum of pathogens affected by Trichoderma sp. is very broad, and includes the following genera: Armillaria, Botrytis, Chondrostereum, Colletotrichum, Dematophora, Diapor- the, Endothia, Fulvia, Fusarium, Fusicladium, Helmin- thosporium, Macrophomina, Monilia, Nectria, Phoma, Phytophthora, Plasmopara, Pseudoperonospora, Pythium, Rhizoctonia, Rhizopus, Sclerotinia, Sclerotium, Venturia, Verticillium (Datnoff et al. 1995; De Melo and Faull 2000; Monte 2001; Tronsmo and Dennis 1977). It is important to notice, that some fungi belonging to Trichoderma genus such as Trichoderma atroviride G79/11 are known to produce cellulases, but also can produce other enzymes, which makes them suitable for antifungal biopreparations (Oszust et al. 2017a, b).

Trichoderma sp. fungi illustrate, the most common mechanisms of antagonism against pathogenic fungi (Fig. 2). There are five main mechanisms involved in attacking other fungi and promoting plant growth: competition for nutrients and space, production of inhibitory compounds, mycoparasitism, inactivation of the pathogen enzymes and induced resistance (Elad et al. 1999; Haran et al. 1996; Lorito et al. 1996; Roco and Pérez 2001; Yedidia et al. 1999, 2000).

Competition is one of the most common biological control activities. Fungi belonging to Trichoderma sp. are known for very fast growth and are treated as aggressive competitor. They quickly colonizes substrates excluding slower growing pathogens such as Fusarium sp. (Papavizas 1985). This property may be very useful for protecting plants by seed treatments, because the protection against pathogens is critical during the germination. Trichoderma sp. added to the soil during seeding or applied beforehand during seed growth along the expanding root system (Harman 2000; Harman et al. 1998; Sivan 1989).

Antibiosis is the antagonisms mechanism of numerous Trichoderma spp. isolates discovered to be capable of producing antibiotic substances. These compounds are often inhibiting the growth of pathogens. For example Howell and Stipanovic (1983) discovered an antibiotic-glovirin, isolated from Trichoderma virens, that was found as a growth inhibitor of Phytophthora species (Howell and Stipanovic 1983). Other studies shown that T. harzianum $\mathrm{T} 12$, and T. koningii $\mathrm{T} 8$ are useful to control of roots rot on peas (Lifshitz and Baker 1986).

Mycoparasitism is another activity taking part in the antipathogenic repertoire of Trichoderma genus members. This mechanism makes Trichoderma spp. a potential biocontrol agents. Trichoderma sp. typically grow towards other fungi hyphae and coil around them. They are able to secrete lytic enzymes that degrade cell walls of pathogenic fungi. This very process is called a mycoparasitism. Special adaptations like hooks, hyphae coiling and appressorium like bodies make it possible to attach to other fungi (Ozbay and Newman 2004). Most fungi belonging to Trichoderma genus are known to produce high amounts of cell-degrading enzymes like $\alpha$-1,3-glucanases and other chitinolytic enzymes. One of the most efficient enzyme producers is Trichoderma harzianum, therefore it is often used in biopreparations. Scientist have also proved that some enzymes produced by antipathogenic fungi inhibit the spore germination and growth of pathogenic fungi hyphae (Szekeres et al. 2004). Studies on the influence of fungi from the genus Trichoderma and Gliocladium on fungal plant pathogen-Botrytis cinerea, growing on strawberries Gliocladium virens (G2 and G8) and T. koningii (T21)revealed maximum inhibition of the pathogen growth. Trichoderma sp. and G. virens managed to colonize and sporulate on sclerotia and caused their lysis within 7-21 days (Alizadeh et al. 2007).

Inhibiting or inactivation pathogen enzymes is another mechanism that enables fungi to control the growth of pathogens. There are specific strains of Trichoderma like T. harzianum $\mathrm{T} 39$ that are able to produce proteases. Those enzymes inactivate pathogen enzymes that are supposed to hydrolyse plant 


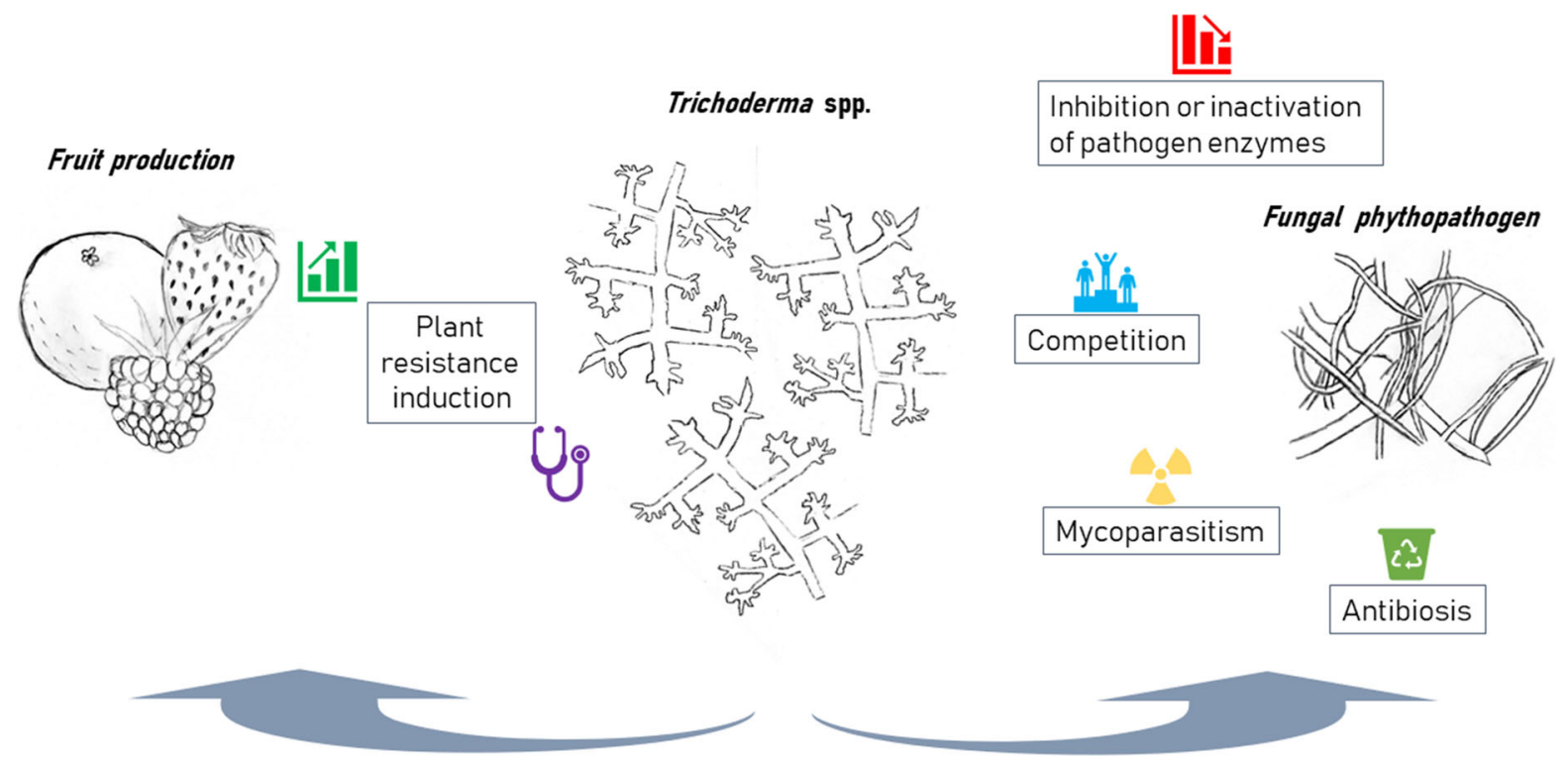

Fig. 2 Presentation of mechanisms involved in attacking other fungi and promoting plant growth

tissues. This strain inhibited growth of Alternaria alternata by over $50 \%$ by degrading endopolygalacturonase (endo-PG) and pectate lysate (Roco and Pérez 2001). Botrytis cinerea is another example of a strawberry pathogen whose's growth is inhibited by fungi of Trichoderma genus. It is producing pectinases, glucanase, cutinase and chitinase, and all those enzymes are suppressed by the protease secreted by Trichoderma sp. (Elad 2000).

Induced resistance is a process of enhancing plant's resistance to pathogens by other organisms. Specific Trichoderma strains are able to colonize plant's root tissues and star a series of biochemical and morphological changes. It induces plant defense response resulting in the activation of induced systemic resistance. It was shown that Trichoderma harzianum T39 applied to the soil can induce systemic resistance in strawberries attacked by powdery mildew, caused by Podosphaera aphanis and consequently inhibit the growth of the pathogen (Harel et al. 2011).

\subsubsection{Pythium oligandrum}

It is a fungus used in biocontrol of strawberry gray mould. Apart from this, it can reduce the growth of leaf spot (Mycosphaerella fragariae) and powdery mildew (Sphaerotheca macularis) of strawberries. Botrytis cinerea is one of the most important strawberry diseases is capable of decreasing the yield by up to $80 \%$. It grows quickly and spreads easily by spores transferred by wind, rain drops or animals, and it can be successfully managed by Pythium oligandrum. $P$. oligandrum has also the cpacity to parasite other fungi e.g. Fusarium oxysporum or Verticillium albo-atrum, by producing enzymes (cellulases or chitinases) that degrade pathogens cell walls (Benhamou et al. 1999). $P$. oligandrum also secretes other extracellular enzymes i.e. lipases, proteases and $\beta$-1,3-glucanases, which affect pathogenic fungi (Picard et al. 2000).

\subsubsection{Talaromyces flavus}

Talaromyces flavus is a fungus widely spread around the world. Talaromyces genus belongs to heat-resistant fungi (HRF) group, and T. flavus is one of the most common fungi belonging to this group. The HRF are known for their ability to withstand high temperature treatment, such as pasteurization process. It is able to survive heating to $90{ }^{\circ} \mathrm{C}$ for $6 \mathrm{~min}$ and to $95{ }^{\circ} \mathrm{C}$ for $1 \mathrm{~min}$ in glucose tartrate heating medium of $\mathrm{pH} 5.0$ and $16^{\circ}$ Brix (Frac 2015; Panek and Frąc 2018). It is also known for its ability to produce bioactive compounds such as actofunicone, deoxy- funicone and vermistatin (Proksa 2010). Because of these 
compounds and their ability to grow fast and compete for nutrients it is a promising material for further research in the field of pathogen biocontrol. Dethoup et al. (2007) has shown the ability to control the growth of Phytophthora palmivora, P. parasitica, Colletotrichum capsici, C. gloeosporioides, Fusarium oxysporum by Talaromyces flavus in in vitro conditions (Dethoup et al. 2007).

\subsubsection{Aureobasidium pullulans}

Another microorganism commonly used around the world in strawberry farming is Aureobasidium pullulans, because its high efficacy in the strawberry protection against Botrytis cinerea and Rhizopus stolonifer. It is a fungus similar to yeast colonizing plants in their natural habitat (Mounir et al. 2007). The development of Aureobasidium pullulans depends on many factors such as temperature, $\mathrm{pH}$ value, nutrient availability in the substrate. Its efficacy in strawberry protection has been proved by many scientists (Lima et al. 1997; Prokkola and Kivijärvi 2007; Sylla et al. 2013; Wagner and Hetman 2016). These fungi compete with other fungi for space and nutrients, they might be a direct parasite of pathogenic fungi and they produce antimicrobial enzymes and antibiotics (Chi et al. 2009). The anipathogenic effect and reduced severity of the disease is not yet fully understood and it is suspected to be a reaction on a many different levels. Fungal competition for nutrients and space weakens pathogen's cells and makes them more receptive to host enzymes and potential antibiotic compounds produced by the plant or the antagonist (Adikaram et al. 2002). Aureobasidium pullulans L47 was proven to be the most effective against both $B$. cinerea and $R$. stolonifer (Lima et al. 1997).

\subsubsection{Arbuscular mycorrhizal fungi}

Arbuscular mycorrhizal fungi are organisms similar in their effects to plant growth promoting rhizobacteria (PGPR), they are obligate symbionts, belonging to the phylum Glomeromycota (Berruti et al. 2016). They have the capacity to develop a symbiotic association with plants. This relationship provides benefits for both fungi and plants e.g. fungi enhances the growth of roots and increases theirs surface area, which improves provision of water and nutrients. Even though the symbiosis is not specific it has been found, that some combinations of fungi and plants are more effective in different conditions (Miransari 2011). They can be used as biofertilisers and are useful in organic farming of fruits increasing their yields and decreasing effects of environmental stresses (Berruti et al. 2016; Stewart et al. 2005; Zardak et al. 2018).

\subsection{Bacteria}

\subsubsection{Bacillus spp.}

As it was mentioned earlier the gray mould of strawberries is one of the most economically important diseases in strawberry farming. It has been reported, that not only fungi, but also some bacteria can help with controlling this disease. Bacillus lentimorbus, B. megaterium, B. pumilis, B. subtilis are species capable of inhibiting the growth of $B$. cinerea during in vitro studies. They were not only inhibiting the growth itself but also reducing the conidia germination on strawberry fruits by up to $80 \%$ (Donmez et al. 2011).

\subsubsection{Pseudomonas fluorescens}

Pseudomonas sp. is a commonly occurring fungi in almost all cultivated areas. This genus and especially the species Pseudomonas fluorescens are widely studied with respect to biocontrol activities. One of the strains that is particularly important for organic farming is Pseudomonas fluorescens Pf-5. It grows quickly, produces siderophores, which might act as a growth factors and phenazines. Phenazines are a large group of compounds that act as a growth stimulator in plants. They also have the capacity to elicit induced systemic resistance (Pierson and Pierson 2010). Their ability to inhibit the growth of $B$. cinerea on strawberries has been demonstrated both in vitro and in vivo. The bacterial inoculum was added to $0.01 \%$ glycerol oil and used through foliar application on strawberry plants. The research has proven that due to this treatment severity of the disease were decreased in comparison with fungicide (Haggag and Abo El Soud 2012).

\subsubsection{LAB: lactic acid bacteria}

It is a wide group of bacteria, consisting of different species capable of producing lactic acid during 
fermentation. Some of them have been categorized by the U.S. Food and Drug Administration as Generally Regarded as Safe (GRAS) and by the European Food Safety Authority as having Qualified Presumption of Safety. Some LAB bacteria produce biologically active compounds, for instance bacteriocins or organic acids (Reis et al. 2012). Current research has shown, that two strains of Lactobacillus plantarum PM411 and TC92 prevented Xanthomonas fragariae in strawberry. $X$. fragariae is a bacterial plant pathogen causing the angular leaf spot of strawberry. It spreads mostly via water drops splashing or via mechanical means during the farming or harvesting. Strawberries were sprayed with the inoculum at $10^{8} \mathrm{CFU} \mathrm{ml} \mathrm{m}^{-1}$ concentration. The bacteria were able to live on the leaves at the concentration of about $10^{4} \mathrm{CFU}$ per leaf. The test strains reduced disease incidence from $40 \%$ to 10-12\% (Daranas et al. 2018).

\section{Examples of commercially available biopreparations and bioproducts}

Biopreparations are substances obtained from a living organism or even its metabolites. However materials, chemicals and energy derived from renewable biological resources are called bioproducts (Singh et al. 2003). There are many of biopreparations and bioproducts used in organic fruit production e.g. Micosat F, Biosept 33 SL. They are based on different active ingredient such as microbial inoculum (e.g. Pythium oligandrum), plant extracts (e.g. Allium sativumgarlic), or substances derived from animals (e.g. chitosan). Table 1 presents examples of plant derived bioproducts that have been found as effective in biocontrol of some fungal pathogens. Those biopreparations are valued by farmers due to their effectiveness and safety not only for plants themselves but also for animals (Bala et al. 2009; Marjanska-Cichon and Sapieha-Waszkiewicz 2011; Reddy et al. 2000).

\subsection{Bioproducts and biopreparations based on microbial components}

Polyversum WP is a biopreparation consisting a mixture of Pythium oligantrum spores. Pythium oligandrum is a fungus that is capable of mycoparasiting common plant pathogenic fungi. Intensive research has found that they are capable of inducing plant's resistance, enhance plant's growth, and produce hydrolytic enzymes, e.g. cellulases or chitinases. It has been found, that lyophilized filtrate after $P$. oligantrum culture, diluted to proper concentration $(1: 10,1: 100)$ is capable of inhibiting the growth of Botrytis cinerea causing grey mould disease of strawberries, one of the most dangerous strawberry pathogens in contemporary agriculture (Bala et al. 2009).

Micosat $\mathrm{F}$ is a biopreparation produced by an Italian company CCS Aosta. It is a composition of arbuscular mycorrhizal fungi: Glomus species, Trichoderma viride, and rhizosphere bacterial species (Bacillus subtilis, Pseudomonas fluorescens and Streptomyces spp.). This biopreparation contains $40 \% \mathrm{C}, 0.15 \% \mathrm{~N}$, $431 \mathrm{mg} \mathrm{kg}^{-1} \mathrm{P}$ and $9.558 \mathrm{mg} \mathrm{kg}^{-1} \mathrm{~K}$ and comes in the form of granules. Such microorganisms live in symbiosis with a wide variety of cultivated crops and enhance plant's nutrient uptake. Furthermore they reduce the influence of environmental stress, such as drought, on plants. The research into the influence of this biopreparation onto the growth of fruits in organic farming was conducted and revealed that the biopreparation enhances the growth of apple trees ('Topaz') and sour cherry ('Debreceni Bötermö') (Grzyb et al. 2015).

Trianum-P (Koppert BV, Netherlands) is a biopreparation containing Trichoderma harzianum Rifai strain T-22. It come in the form of granules to be dissolved in water. This biopreparation contains $10^{9}$ CFU spores of $T$. harzianum $\mathrm{g}^{-1}$ of bioproduct that are capable of germinating and growing in a variety of soils, and different $\mathrm{pH}$ values (4-8.5). It decreases the infection rate of Fusarium sp., Rhizoctonia sp., Pythium sp. on different plants including strawberries. This species of Trichoderma is known for its capacities to produce antibiotic substances, enhance root growth, and stimulate plants defence systems (Benítez et al. 2004). Similar biopreparations basing on $T$. harzianum are commercially available as fungicides in the following countries the Czech Republic (Supresivit), USA (T-Gro), Australia (Rootshield WP), New Zeland (Trichodex) (Woo et al. 2014).

Worth mentioning is the broad spectrum of humus bioproducts. They consist of many beneficial organisms like bacteria or fungi, and organic matter created during the humification processes. Due to their properties (active microorganisms and complex chemical compounds) it is often sold as a liquid prepared to 
Table 1 Biological control of fungal pathogens

\begin{tabular}{|c|c|c|c|}
\hline Plant & Bioproduct & Pathogen & References \\
\hline Garlic (Allium sativum) & Extract & $\begin{array}{l}\text { Alternaria } \text { spp. } \\
\text { Phytophtora infestans }\end{array}$ & Slusarenko et al. (2008) \\
\hline $\begin{array}{l}\text { Lemon grass (Cymbopogon citratus) } \\
\text { Basil (Ocimum basilicum) }\end{array}$ & Essential oil & $\begin{array}{l}\text { Phytophthora capsicum } \\
\text { Phytophthora drechsleri } \\
\text { Phytophthora melonis }\end{array}$ & Amini et al. (2016) \\
\hline Neem (Azadirachta indica) & Seed kernel extract & $\begin{array}{l}\text { Monilinia fructicola, } \\
\text { Penicillium expansum } \\
\text { Trichothecium roseum } \\
\text { Alternaria alternata }\end{array}$ & Wang et al. (2010) \\
\hline $\begin{array}{l}\text { Oleander (Nerium oleander) } \\
\text { Monkeypod (Pithecolobium dulce) }\end{array}$ & Oil cake & Bipolaris oryzae & Harish et al. (2008) \\
\hline Thyme (Thymus vulgaris) & Essential oil & $\begin{array}{l}\text { Aspergillus flavus } \\
\text { Fusarium moniliforme }\end{array}$ & Massoud et al. (2012) \\
\hline Warionia saharae & Essential oil & $\begin{array}{l}\text { Alternaria spp. } \\
\text { Penicillium expansum } \\
\text { Rhizopus stolonifer }\end{array}$ & Znini et al. (2013) \\
\hline Wild betel (Piper sarmentosum) & Extract & Colletotrichum gloeosporioides & Bussaman et al. (2012) \\
\hline
\end{tabular}

dilution. They are predominantly applied in a diluted form directly to the soil near the plants. Biopreparations used this way: Humus UP (Ekodarpol, Poland), Wspomag (BIOHUMUSECO, Poland), HUMVITEKO UNIWERSALNY (BIOHUMUSECO, Poland), TOTALHUMUS (THE, Poland), BIO-HUMUS EXTRACT "RASKILA” (LLC EKO ZEME, Latvia). Some of the bioproducts like WORM HUMUS (Humus Versol, Spain), or BIO-HUMUS (LLC EKO ZEME, Latvia) are soil-like formulations, and should be mixed with soil before planting in 1:5 ratio (Derkowska et al. 2015; Piotrowski et al. 2015).

Seaweed biopreparations such as Alga 600 (Agrocoast, USA) are another type of commercially available and useful biopreparations. Most of the seaweed extracts are derived from Ascophyllum nodosum, Fucus spp., Laminaria spp., Sargassum spp., and Turbinaria spp. (Hong et al. 2007; Ugarte et al. 2006). They stimulate the growth of roots and upper parts of plants and enhance the yield in strawberry plants (Alam et al. 2013).

\subsection{Plant extracts, and other type of bioproducts}

Plants are known for the production of aromatic secondary metabolites such as phenols, phenolic acids, quinones, flavones, flavonoids, flavonols, tannins and coumarins. Some of them like carvacrol, eugenol or thymol may inhibit the growth of the pathogens due to their phenolic structures. The compounds have antimicrobial properties and they are a part of plants defence mechanisms (Das et al. 2010; Gurjar et al. 2012). Plant extracts, and other type of bioproducts described in this section are depicted at Fig. 3.

Plant extracts (PE) are eco-friendly and biodegradable, so they can be used in organic farming. Moreover, they are often cheaper than conventional fungicides. One of the most important steps in preparing a plant extract is choosing the proper plant material and the method of extraction. Some researchers recommend preparing $\mathrm{PE}$ from fresh plant materials, because the presence of some active compounds prone to degradation. Many plants are used in a dry form, due to different water content in plants. They are air dried before extraction to maintain the same amount of plant tissue in a sample (Salie et al. 1996; Tiwari et al. 2012). Choosing a right solvent is important for the extracting maximum of active substance. Even though water is the most common solvent for preparing plant extracts, it has been found that substances extracted with organic solvent display more consistent antimicrobial activity. For this reason 


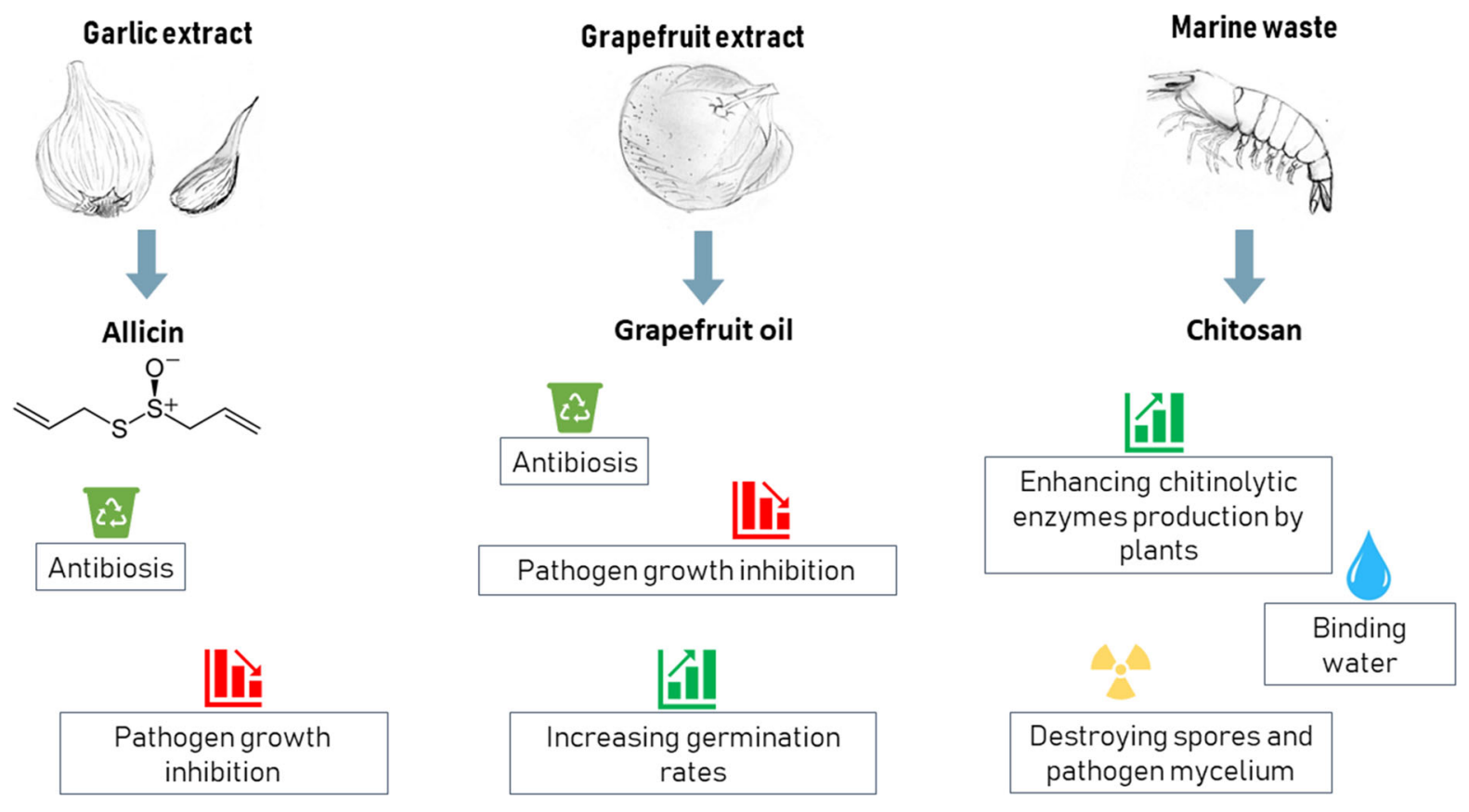

Fig. 3 Presentation of different sources of bioproducts and properties of such bioproducts

most of identified antimicrobial compounds are aromatic or saturated organic compounds, and they are mostly extracted using organic solvents like methanol or ethanol (Härmälä et al. 1992; Parekh et al. 2004). It is important to maintain a standardised extraction and solvents to decrease the variation in PE's antimicrobial activity. Plant material should be ground into small particles. Research has shown that 5-min extraction of $10 \mu \mathrm{m}$ plant particles resulted in higher yield than a $24 \mathrm{~h}$ extraction of larger particles (Eloff 1998). Various plants can be used as sources of bioproducts useful in plant disease management for example turmeric (Curcuma longa Linn.), ginger (Zingiber officinale Rosc.)—Phytopthora infestans, neem/margosa (Azadirachta indica A. Juss.) - Alternaria alternata, holy basil (Oscimum sanctum Linn.), peach (Prunus persica Linn.)-Botrytis cinerea, oregano (Origanum hercleoticum)-Fusarium oxysporum (Gurjar et al. 2012).

Garlic extract is one of the most common used in biocontrol is. Slicing or crushed garlic cloves result in mixing of vacuolar enzyme alliin lyase and its substrate-alliin. The product of this reaction is thiosulphenic acid, which immediately and spontaneously dimerises to diallylthiosulphinate-allicin. This is the very compound that gives garlic its characteristic smell (Slusarenko et al. 2008). Allicin has been known to be a major antimicrobial substance in garlic since 1944 and it has been reported to be effective against a wide range of plant pathogens (Curtis et al. 2004). It has been proven that garlic extract is capable of inhibiting the growth of Phytophthora infestans both in vitro and in field studies. Researchers have studied the application of garlic extract or allicin both as foliar spray $\left(100 \mu \mathrm{g} \mathrm{ml}^{-1}\right)$ and as alginate capsules applied to the soil around Phytophtora-inoculated plants. They have found that both ways of application were effective. It also has been proven that they are effective in seed priming reducing the Alternaria spp. infections after germination in carrot plants (Slusarenko et al. 2008). Garlic extract acquired by ethanol and water extraction from dried garlic cloves has been found capable of inhibiting the growth of $B$. cinerea. $40 \%$ aqueous garlic extract reduced the mycelial growth by $92 \%$, and $60 \%$ and $80 \%$ extracts reduced the growth by $100 \%$. $40 \% \leq$ concentration of water extract inhibited all conidial germination of Botrytis cinerea (Daniel et al. 2015). One of the biopreproducts that contains garlic extract is Bioczos Płynny (Himal, Poland). It has been found to reduce the severity of grey mould disease in strawberries, and its efficacy was comparable to 
commercially available fungicide-Switch $62.5 \mathrm{WG}$ (cyprodynil + fludioxonil) (Marjanska-Cichon and Sapieha-Waszkiewicz 2011).

Another plant extract used in biopreparations, e.g. in Biosept $33 \mathrm{SL}$ is $33 \%$ grapefruit extract (GE). It is derived from both the pulp and the seeds of grapefruit (Citrus paradise) (Xu et al. 2007). It contains a broad variety of antibiotic substances such as endogenous flavonoids, and it does not have any observed side effects. Studies upon the grapefruit extract showed, that it act as a strong growth inhibition in many species of bacterial and fungal plant pathogens (Jamiołkowska 2009). It has been proved that dressage of seeds with $0.2 \%$ Biosept 33 SL causes better germination and fewer diseases in plants like peas or bean. It also decreased an amount of plant pathogenic fungi such as $F$. oxysporum, A. alternata, B. cinerea isolated from those plants in later studies (Patkowska 2006). Grapefruit extract has also been proven to inhibit the spore germination of $B$. cinerea in vitro and in vivoon grape berries. A $0.5 \%$ grapefruit extract showed better efficacy that commonly used fungicide $(0.1 \%$ of thiabendazole) during in vitro studies-only $14 \%$ of spores germinated in the sample treated with GE, and $29 \%$ in the sample treated with thiabendazole. The immersion of grapes in $0.5 \%$ GE was significantly more effective than the immersion in $0.1 \%$ thiabendazole resulting in 17.2 infected berries per kilogram of fruits and 23.2 infected berries per kilogram of fruit respectively (Xu et al. 2007).

Chitosan is one of the modern bioproducts and is found inter alia in biopreparations such as BIOCHIKOL (earlier Biochikol 020 PC) produced by Poli-Farm. It is a polymer produced from the chitin elements of arthropod's exoskeleton and marine waste (Reddy et al. 2000). Many researchers have proved that it can be effective in the plant protection against pathogenic fungi (El Ghaouth et al. 1991a, b). Apart from inhibiting growth of pathogens chitosan also induces an increase in the activity of chitinase and phytoalexines production in plants which enables the treated plants to destroy pathogen's cell walls (El Hadrami et al. 2010). Phytoalexines are antimicrobial substances that are capable of accumulating rapidly in the areas of pathogen infection (Urban et al. 2004). Chitosan can also bind water to make a moisture barrier and delay the aging process in plants which lowers the rate of fungi infections (Reddy et al. 2000). Moreover, the compound can directly damage pathogenic fungi by destroying spores and mycelium (Urban et al. 2004). An experiment with $10 \mathrm{~g} \mathrm{l}^{-1}$ chitosan applied as a foliar spray to strawberry plants resulted in effective controlling of the infection of $B$. cinerea in strawberries. Furthermore, the studies show that to maintain the efficacy of this treatment chitosan should be applied regularly in 10-days intervals (Reddy et al. 2000). Researchers have proved, that foliar application of 500 and $1000 \mathrm{ppm}$ chitosan solution previously dissolved in $0.1 \mathrm{~N} \mathrm{HCl}$ and diluted with distilled water with $\mathrm{pH}$ adjusted at 6.5 by 0.1 $\mathrm{NaOH}$ resulted in significant enhancement of plants height, root length, total fruit weight, total anthocyanins, carotenoids, total flavonoids, phenolics contents and antioxidant activity of fresh strawberry fruits (Rahman et al. 2018).

It is instructive to compare conventional chemical fungicides to commercially available biopreparations as far as phytopathogen controlling effectiveness. Polyversum WP (Target, Poland), a biopreparation containing Pythium oligandrum showed similar results in reducing the severity of grey mold, leaf spot and powdery mildew on strawberries in field tests. The efficiency of this product was the same or only a little lower than fungicides (Signum 33 WG (boscalid + piraclostrobin), Folpan 80 WG (folpet), Teldor 500 SC (fenhexamid) and against leaf spot and powdery mildew: Domark 100 EC (tetraconazole), Zato 50 WG (trifloxystrobin), Topsin M 500 SC (thiophanate methyl) (Meszka and Bielenin 2010). Biosept 33 SL (Target, Poland) and Biochikol 020 PC (Poli-Farm. Poland) are biopreparations made out of bioproducts-Biosept 33 SL contains grapefruit oil, and Biochikol $020 \mathrm{PC}$ contains chitosan. Both of them were tested to determine their ability to inhibit development of Topospora myrtilli (Feltg.) Boerema on stems of highbush blueberry. Both biopreparations tested inhibited the growth of pathogen, but their protective effects were weaker compared to Dithane M45 80WP containing mancozeb (Szmagara 2008). Another research shows that combining conventional fungicides with biopreparations might lead to the reduction of the amount of fungicides required. The application of Serenade biopreparation (Bayer, Germany) containing Bacillus subtilis QST 713 with Fracture fungicide (CEV, Portugal) containing BLAD polypeptide results in controlling Botrytis blossom blight affecting wild blueberries. The research has 
shown that fungicide usage can be reduced without loses in disease control (De Curtis et al. 2019).

It should be borne in mind that management systems might affect soil microorganisms. One of the purposes of using biopreparations is to increase soil biodiversity. Applying organic fertilizers, soil tillage or cover crops may change the expected output of the use of biopreparations. Cover crops produce root exudates, which are C-rich compounds such as amino acids, organic acids, phenolics and secondary metabolites. All these substances are attractive for microbes including arbuscular mycorrhizal fungi and nitrogen fixing bacteria (Vukicevich et al. 2016) and also cover crops may enhance the soil microbial community by providing a legacy of increased microbial biomass $\mathrm{P}$, and phosphatase activity (Hallama et al. 2018). Due to this, it can be expected that the addition of biopreparations based on microorganisms will enhance soil biodiversity even more and cover crops increasing soil moisture by cover crops might enhance their survivability (De Vries et al. 2012). However, it should be borne in mind that unfortunately increasing soil diversity by cover crops might also lead to the increase in the amount of host specific plant pathogens as a result of pathogens being attracted to root exudates (Hofmann et al. 2009). Soil tillage is another agricultural management practice that can directly affect soil microorganisms, and thus needs to be taken into consideration when using biopreparations because it negatively affects most soil microbes (López-Piñeiro et al. 2013). Tillage, in turn leads to the reduction of both AM fungi and plant growth promoting bacteria (Brito et al. 2012; Lupwayi et al. 1998). Nevertheless, tillage might be mandatory in some specific circumstances, e.g., replanting, but the loss of soil microbial diversity caused by tillage might be counterproductive when applying microbial based biopreparations. Moreover, tillage in some cases have a positive effect on soil suppressiveness to phytopathogens (Bongiornoa et al. 2019). Organic fertilizers are known to increase organic matter content in soil which lead to increased amount of fungi and bacteria in soil. Furthermore, the soil treated with organic fertilizers is characterized by better water retention and higher amount of organic compounds. Using organic fertilizers in known to be beneficial for both plants and microorganisms. The use of both organic fertilizers and biopreparations can have positive effects on the soil and the plants (Escobar and
Solarte 2015), however on the basis of long term experiments the effect of organic matter addition on soil suppressiveness to Pythium ultimum was not significant (Bongiornoa et al. 2019).

\section{Summary and future targets}

There are many ways to help plants grown in organic horticulture. The ban on the use of conventional plant protectants has led to increased demand for now, biologically based products. Properly prepared and tested preparations may be the future of agriculture. The use of biopreparations can contribute to maintaining a proper soil structure, high content of organic matter, increased water retention, or an increase in the number of beneficial soil microorganisms. Reducing the amount of mineral fertilizers and chemical fungicides can contribute to increase of biodiversity in arable areas. The EU laws and especially Council Directive of 12 December 1991 concerning the protection of waters against pollution caused by nitrates from agricultural sources (91/676/EEC) should be taken into account in the context mineral fertilizers; the laws state, that the amount of nitrogen containing fertilizers used in agriculture and horticulture should be reduced. Taking everything into consideration, future research should focus on developing new bioproducts, new biopreparations, and formulations, as well as testing their effect in practice.

Acknowledgements The work was financed by The National Centre for Research and Development in frame of the project BIOSTRATEG, contract number BIOSTRATEG3/344433/16/ NCBR/2018. Agnieszka Frąc kindly produced drawings.

Open Access This article is distributed under the terms of the Creative Commons Attribution 4.0 International License (http:// creativecommons.org/licenses/by/4.0/), which permits unrestricted use, distribution, and reproduction in any medium, provided you give appropriate credit to the original author(s) and the source, provide a link to the Creative Commons license, and indicate if changes were made.

\section{References}

Adikaram NKB, Joice DC, Terry LA (2002) Biocontrol activity and induced resistance as a possible mode of action for Aureobasidium pullulans against grey mould of strawberry 
fruit. Australas Plant Pathol 31:223-229. https://doi.org/ 10.1071/ap02017

Alam MZ, Braun G, Norrie J, Hodges DM (2013) Effect of Ascophyllum extract application on plant growth, fruit yield and soil microbial communities of strawberry. Can J Plant Sci 93:23-36. https://doi.org/10.4141/cjps2011-260

Alizadeh H, Sharifi-Tehrani A, Hedjaroude G (2007) Evaluation of the effects of chemical versus biological control on Botrytis cinerea agent of gray mould disease of strawberry. Commun Agric Appl Biol Sci 72:795-800

Amini J, Farhang V, Javadi T, Nazemi J (2016) Antifungal effect of plant essential oils on controlling Phytophthora species. Plant Pathol J 32:16-24. https://doi.org/10.5423/ PPJ.OA.05.2015.0091

Bala K, David DR, Paul B, Elad Y (2009) Pythium elicitors in biological control of Botrytis cinerea. IOBC/WPRS Bull 42:11-14

Barbieri G, Colonna E, Rouphael Y, De Pascale S (2015) Effect of the farming system and postharvest frozen storage on quality attributes of two strawberry cultivars. Fruits 70:351-360. https://doi.org/10.1051/fruits/2015036

Barłowska J, Wolanciuk A, Idec J (2017) Rolnictwo ekologiczne w Polsce na tle Unii Europejskiej i świata. Przegl Hod 2:2-5 (in Polish)

Battacharyya D, Babgohari MZ, Rathor P, Prithiviraj B (2015) Seaweed extracts as biostimulants in horticulture. Sci Hortic 196:39-48. https://doi.org/10.1016/j.scienta.2015. 09.012

Benhamou N, Rey P, Picard K, Tirilly Y (1999) Ultrastructural and cytochemical aspects of the interaction between the mycoparasite Pythium oligandrum and soilborne plant pathogens. Phytopathology 89:506-517. https://doi.org/10. 1094/PHYTO.1999.89.6.506

Benítez T, Rincón AM, Limón MC, Codón AC (2004) Biocontrol mechanisms of Trichoderma strains. Int Microbiol 7:249-260

Berg A, Kemami Wangun HV, Nkengfack AE, Schlegel B (2004) Lignoren, a new sesquiterpenoid metabolite from Trichoderma lignorum HKI 0257. J Basic Microbiol 44:317-319. https://doi.org/10.1002/jobm.200410383

Berruti A, Lumini E, Balestrini R, Bianciotto V (2016) Arbuscular mycorrhizal fungi as natural biofertilizers: let's benefit from past successes. Front Microbiol 6:1-13. https://doi.org/10.3389/fmicb.2015.01559

Berry PM, Sylvester-Bradley R, Philipps L, Hatch DJ, Cuttle SP, Rayns FW, Gosling P (2002) Is the productivity of organic farms restricted by the supply of available nitrogen? Soil Use Manag 18:248-255. https://doi.org/10.1079/ SUM2002129

Bhardwaj D, Ansari MW, Sahoo RK, Tuteja N (2014) Biofertilizers function as key player in sustainable agriculture by improving soil fertility, plant tolerance and crop productivity. Microb Cell Fact 13:1-10. https://doi.org/10.1186/ 1475-2859-13-66

Boddey RM, Urquiaga S, Reis V, Döbereiner J (1991) Biological nitrogen fixation associated with sugar cane. In: Polsinelli M, Materassi R, Vincenzini M (eds) Nitrogen fixation: proceedings of the fifth international symposium on nitrogen fixation with non-legumes. Springer, Dordrecht, pp 105-111. https://doi.org/10.1007/978-94-0113486-6_22
Bongiornoa G, Postma J, Bünemann EK, Brussaard L, de Goede RG, Mäder P, Tamm L, Thuerig B (2019) Soil suppressiveness to Pythium ultimum in ten European long-term field experiments and its relation with soil parameters. Soil Biol Biochem 133:174-187. https://doi.org/10.1016/j. soilbio.2019.03.012

Brito I, Goss MJ, de Carvalho M, Chatagnier O, van Tuinen D (2012) Impact of tillage system on arbuscular mycorrhiza fungal communities in the soil under Mediterranean conditions. Soil Tillage Res 121:63-67. https://doi.org/10. 1016/j.still.2012.01.012

Bussaman P, Namsena P, Rattanasena P, Chandrapatya A (2012) Effect of crude leaf extracts on Colletotrichum gloeosporioides (Penz.) Sacc. Psyche A J Entomol 1:1. https://doi.org/10.1155/2012/309046

Calvo P, Nelson L, Kloepper JW (2014) Agricultural uses of plant biostimulants. Plant Soil 383:3-41. https://doi.org/ 10.1007/s11104-014-2131-8

Canellas LP, Olivares FL, Aguiar NO, Jones DL, Nebbioso A, Mazzei P, Piccolo A (2015) Humic and fulvic acids as biostimulants in horticulture. Sci Hortic 196:15-27. https:// doi.org/10.1016/j.scienta.2015.09.013

Cerdán M, Sánchez-Sánchez A, Jordá DJ, Juárez M, Andreu JS (2013) Effect of commercial amino acids on iron nutrition of tomato plants grown under lime-induced iron deficiency. J Plant Nutr Soil Sci 176:1-8. https://doi.org/10.1002/jpln. 201200525

Chi Z, Wang F, Chi Z, Yue L, Liu G, Zhang T (2009) Bioproducts from Aureobasidium pullulans, a biotechnologically important yeast. Appl Microbiol Biotechnol 82:793-804. https://doi.org/10.1007/s00253-009-1882-2

Colla G, Rouphael Y (2015) Biostimulants in horticulture. Sci Hortic 196:1-2. https://doi.org/10.1016/j.scienta.2015.10. 044

Colla G, Rouphael Y, Canaguier R, Svecova E, Cardarelli M (2014) Biostimulant action of a plant-derived protein hydrolysate produced through enzymatic hydrolysis. Front Plant Sci 5:1-6. https://doi.org/10.3389/fpls.2014.00448

Colla G, Rouphael Y, Di Mattia E, El-Nakhel C, Cardarelli M (2015a) Co-inoculation of Glomus intraradices and Trichoderma atroviride acts as a biostimulant to promote growth, yield and nutrient uptake of egetable crops. J Sci Food Agric 95:1706-1715. https://doi.org/10.1002/jsfa. 6875

Colla G, Nardi S, Cardarelli M, Ertani A, Lucini L, Canaguier R, Rouphael Y (2015b) Protein hydrolysates as biostimulants in horticulture. Sci Hortic 196:28-38. https://doi.org/10. 1016/j.scienta.2015.08.037

Curtis H, Noll U, Störmann J, Slusarenko AJ (2004) Broadspectrum activity of the volatile phytoanticipin allicin in extracts of garlic (Allium sativum L.) against plant pathogenic bacteria, fungi and Oomycetes. Physiol Mol Plant Pathol 65:79-89. https://doi.org/10.1016/j.pmpp.2004.11. 006

Daniel CK, Lennox CL, Vries FA (2015) In-vitro effects of garlic extracts on pathogenic fungi Botrytis cinerea, Penicillium expansum and Neofabraea alba. S Afr J Sci 111:1-8. https://doi.org/10.17159/sajs.2015/20140240

Daranas N, Roselló G, Cabrefiga J, Donati I, Francés J, Badosa E, Spinelli F, Montesinos E, Bonaterra A (2018) Biological control of bacterial plant diseases with Lactobacillus 
plantarum strains selected for their broad-spectrum activity. Ann Appl Biol. https://doi.org/10.1111/aab.12476

Das K, Tiwari RKS, Shrivastava DK (2010) Techniques for evaluation of medicinal plant products as antimicrobial agent: current methods and future trends. J Med Plants Res 4:104-111. https://doi.org/10.5897/JMPR09.030

Datnoff LE, Nemec S, Pernezny K (1995) Biological control of fusarium crown and root rot of tomato in florida using Trichoderma harzianum and Glomus intraradices. Biol Control 5:427-431. https://doi.org/10.1006/bcon.1995. 1051

De Curtis F, Ianiri G, Raiola A, Ritieni A, Succi M, Tremonte P, Castoria R (2019) Integration of biological and chemical control of brown rot of stone fruits to reduce disease incidence on fruits and minimize fungicide residues in juice. Crop Protect 119:158-165. https://doi.org/10.1016/j. cropro.2019.01.020

De Melo IS, Faull JL (2000) Parasitism of Rhizoctonia solani by strains of Trichoderma spp. Sci Agric. https://doi.org/10. 1590/S0103-90162000000100010

De Pascale S, Rouphael Y, Colla G (2017) Plant biostimulants: innovative tool for enhancing plant nutrition in organic farming. Eur J Hortic Sci 82:277-285. https://doi.org/10. 17660/eJHS.2017/82.6.2

De Ponti T, Rijk B, Van Ittersum MK (2012) The crop yield gap between organic and conventional agriculture. Agric Syst 108:1-9. https://doi.org/10.1016/j.agsy.2011.12.004

De Vries F, Manning P, Tallowin JRB, Mortimer SR, Pilgrim ES, Harrison KA, Hobbs PJ, Quirk H, Shipley B, Cornelissen JHC, Kattge J, Bardgett RD (2012) Abiotic drivers and plant traits explain landscape-scale patterns in soil microbial communities. Ecol Letters 15(11):1230-1239. https://doi.org/10.1111/j.1461-0248.2012.01844.x

Derkowska E, Sas-Paszt L, Harbuzov A, Sumorok B (2015) Root growth, mycorrhizal frequency and soil microorganisms in strawberry as affected by biopreparations. Adv Microbiol 1:65-73. https://doi.org/10.4236/aim.2015. 51007

Dethoup T, Manoch L, Visarathanonth N, Chamswarng C, Kijjoa A (2007) Morphology and distribution of Talaromyces flavus from soil and potential use as a biological control agent against plant pathogenic fungi. Thai J Agric Sci 40:37-50

Donmez MF, Esitken A, Yildiz H, Ercisli S (2011) Biocontrol of Botrytis cinerea on strawberry fruit by plant growth promoting bacteria. J Anim Plant Sci 21:758-763

Dorais M, Alsanius B (2015) Advances and trends in organic fruit and vegetable farming research. Hortic Rev (Am Soc Hortic Sci) 43:185-267. https://doi.org/10.1002/ 9781119107781.ch04

du Jardin P (2015) Plant biostimulants: definition, concept, main categories and regulation. Sci Hortic 196:3-14. https://doi. org/10.1016/j.scienta.2015.09.021

El Ghaouth A, Arul J, Ponnampalam R, Boulet M (1991a) Chitosan coating effect on storability and quality of fresh strawberries. J Food Sci 56:1618-1620. https://doi.org/10. 1111/j.1365-2621.1991.tb08655.x

El Ghaouth A, Grenier J, Arul J, Asselin A (1991b) Glucanohydrolases and inhibitory activity of Botrytis cinerea in extracts of strawberry fruits. Can J Plant Pathol $13: 315-320$
El Hadrami A, Adam LR, El Hadrami I, Daayf F (2010) Chitosan in plant protection. Mar Drugs 8:968-987. https:// doi.org/10.3390/md8040968

Elad Y (2000) Biological control of foliar pathogens by means of Trichoderma harzianum and potential modes of action. Crop Prot 19:709-714. https://doi.org/10.1080/ 09583150050115089

Elad Y, David D-RR, Levi T, Kapat A, Kirshner B, Guvrin E, Levine A, Lyr H, Russell PE, Dehne HW, Sisler HD (1999) Trichoderma harzianum T39-mechanisms of biocontrol of foliar pathogens. In: Modern fungicides and antifungal compounds II: 12th International Reinhardsbrunn Symposium, Friedrichroda, Thuringia, Germany, 24th 29th May 1998, pp 459-467

El-Katatny MH, Somitsch W, Robra KH, El-Katatny MS, Gubitz GM (2000) Production of chitinase and $\beta$-1,3-glucanase by Trichoderma harzianum for control of the phytopathogenic fungus, Sclerotium rolfsii. Food Technol Biotechnol 8(3):173-180

Eloff JN (1998) Which extractant should be used for the screening and isolation of antimicrobial components from plants? J Ethnopharmacol 60:1-8. https://doi.org/10.1016/ S0378-8741(97)00123-2

Ertani A, Cavani L, Pizzeghello D, Brandellero E, Altissimo A, Ciavatta C, Nardi S (2009) Biostimulant activity of two protein hydrolyzates in the growth and nitrogen metabolism of maize seedlings. J Plant Nutr Soil Sci 172:237-244. https://doi.org/10.1002/jpln.200800174

Escobar N, Solarte V (2015) Microbial diversity associated with organic fertilizer obtained bycomposting of agricultural waste. Int J Biosci Biochem Bioinform 5:70-79. https:// doi.org/10.17706/ijbbb.2015.5.2.70-79

Etesami H (2018) Can interaction between silicon and plant growth promoting rhizobacteria benefit in alleviating abiotic and biotic stresses in crop plants? Agric Ecosyst Environ 253:98-112. https://doi.org/10.1016/j.agee.2017. 11.007

Farrell M, Prendergast-Miller M, Jones DL, Hill PW, Condron LM (2014) Soil microbial organic nitrogen uptake is regulated by carbon availability. Soil Biol Biochem 77:261-267. https://doi.org/10.1016/j.soilbio.2014.07.003

Forde BG, Lea PJ (2007) Glutamate in plants: metabolism, regulation, and signalling. J Exp Bot 58:2339-2358. https://doi.org/10.1093/jxb/erm121

Frąc M (2015) Occurrence, detection, and molecular and metabolic characterization of heat-resistant fungi in soils and plants and their risk to human health. Adv Agron 132:161-204. https://doi.org/10.1016/bs.agron.2015.02. 003

Frąc M, Hannula SE, Bełka M, Jędryczka M (2018) Fungal biodiversity and their role in soil health. Front Microbiol 9:707. https://doi.org/10.3389/fmicb.2018.00707

García-Mina JM, Antolín MC, Sanchez-Diaz M (2004) Metalhumic complexes and plant micronutrient uptake: a study based on different plant species cultivated in diverse soil types. Plant Soil 258:57-68. https://doi.org/10.1023/B: PLSO.0000016509.56780.40

Grzyb ZS, Sas-Paszt L, Piotrowski W, Malusa E (2015) The influence of mycorrhizal fungi on the growth of apple and sour cherry maidens fertilized with different bioproducts in 
the organic nursery. J Life Sci 9:221-228. https://doi.org/ 10.17265/1934-7391/2015.05.005

Gurjar MS, Ali S, Akhtar M, Singh KS (2012) Efficacy of plant extracts in plant disease management. Agric Sci 3:425-433. https://doi.org/10.4236/as.2012.33050

Haggag WM, Abo El Soud M (2012) Production and optimization of Pseudomonas fluorescens biomass and metabolites for biocontrol of strawberry grey mould. Am J Plant Sci 3:836-845. https://doi.org/10.4236/ajps.2012. 37101

Hallama M, Pekrun C, Lambers H, Kandeler E (2018) Hidden miners-the roles of cover crops and soil microorganisms in phosphorus cycling through agroecosystems. Plant Soil 434:7-45. https://doi.org/10.1007/s11104-018-3810-7

Haran S, Schickler H, Oppenheim A, Chet I (1996) Differential expression of Trichoderma harzianum chitinases during mycoparasitism. Phytopathology 86:980-985

Harel YM, Kolton M, Elad Y, Rav-david D, Cytryn E, Borenstein M, Shulchani R, Graber ER (2011) Induced systemic resistance in strawberry (Fragaria ananassa) to powdery mildew using various control agents. IOBC/Wprs Bull 71:47-51

Harish S, Saravanakumar D, Radjacommare R, Ebenezar EG, Seetharaman K (2008) Use of plant extracts and biocontrol agents for the management of brown spot disease in rice. BioControl 53:555-567. https://doi.org/10.1007/s10526007-9098-9

Härmälä P, Vuorela H, Törnquist K, Hiltunen R (1992) Choice of solvent in the extraction of Angelica archangelica roots with reference to calcium blocking activity. Planta Med 58:176-183. https://doi.org/10.1055/s-2006-961424

Harman G (2000) Myths and dogmas of biocontrol: changes in perceptions derived from research on Trichoderma harzianum T-22. Plant Dis. https://doi.org/10.1094/PDIS. 2000.84.4.377

Harman G, Björkman T, Blanchard L (1998) The effect of rhizosphere competence on colonization of sweet corn roots by biocontrol fungi in differing soils. HortScience 33:536. https://doi.org/10.21273/HORTSCI.33.3.526b

Hayat R, Ali S, Amara U, Khalid R, Ahmed I (2010) Soil beneficial bacteria and their role in plant growth promotion: a review. Ann Microbiol 60:579-598. https://doi.org/ 10.1007/s13213-010-0117-1

Hofmann A, Wittenmayer L, Arnold G, Schicber A, Merbach W (2009) Root exudation of phloridzin by apple seedlings (Malus domestica Borkh.) with symptoms of apple replant disease. J Appl Bot Food Qual 82:193-198

Hong DD, Hien HM, Son PN (2007) Seaweeds from Vietnam used for functional food, medicine and biofertilizer. J Appl Phycol 19:817-826. https://doi.org/10.1007/s10811-0079228-x

Howell CR, Stipanovic RD (1983) Gliovirin, a new antibiotic from Gliocladium virens, and its role in the biological control of Pythium ultimum. Can J Microbiol 29(3):321-324. https://doi.org/10.1139/m83-053

Hussein MAM, Hassan MHA, Abo-Elyousr KAM (2014) Biological control of Botrytis allii by Trichoderma viride on onion Allium cepa. World Appl Sci J 32:522-526. https:// doi.org/10.5829/idosi.wasj.2014.32.03.933

Jamiołkowska A (2009) The influence of bio-preparation Biosept 33 SL on fungi colonizing of sweet pepper plants
(Capsicum annuum L.) cultivated in the field. Electron $\mathrm{J}$ Polish Agric Univ Ser Hortic 12:117

Jannin L, Arkoun M, Ourry A, Laîné P, Goux D, Garnica M, Fuentes M, Francisco SS, Baigorri R, Cruz F, Houdusse F, Garcia-Mina JM, Yvin JC, Etienne P (2012) Microarray analysis of humic acid effects on Brassica napus growth: involvement of $\mathrm{N}, \mathrm{C}$ and $\mathrm{S}$ metabolisms. Plant Soil 359:297-319. https://doi.org/10.1007/s11104-012-1191-x

Kiełbasa M (2015) Przyszłość sektora rolno-spożywczego w Polsce w odniesieniu do stanu obecnego. Prog Econ Sci 2:227-238 (in Polish)

Kohler J, Caravaca JAHF, Roldan A (2008) Plant-growth-promoting rhizobacteria and arbuscular mycorrhizal fungi modify alleviation biochemical mechanisms in waterstressed plants Josef. Funct Plant Biol 35:141-151. https:// doi.org/10.1074/jbc.272.16.10639

Kubicek C, Mach R, Peterbauer C, Lorito M (2001) Trichoderma: from genes to biocontrol. J Plant Pathol 83:11-23

Larkin RP (2016) Impacts of biocontrol products on Rhizoctonia disease of potato and soil microbial communities, and their persistence in soil. Crop Prot 90:96-105. https://doi.org/10. 1016/j.cropro.2016.08.012

Leal A, Romero-Arenas O, Rivera A, Huerta LM, Reyes E (2016) Effect of the formulation of seaweed (Porphyra umbilical R.) in biopreparations based on Trichoderma harzianum Rifai. J Pure Appl Microbiol 9:2033-2040

Lifshitz R, Baker R (1986) Mechanism of biological control of preemergence damping-off of pea by seed treatment with Trichoderma spp. Ecol Epidemiol 76:720-725

Lima G, Ippolito A, Nigro F, Salerno M (1997) Effectiveness of Aureobasidium pullulans and Candida oleophila against postharvest strawberry rots. Postharvest Biol Technol 10:169-178. https://doi.org/10.1016/S09255214(96)01302-6

López-Piñeiro A, Muñoz A, Zamora E, Ramírez M (2013) Influence of the management regime and phenological state of the vines on the physicochemical properties and the seasonal fluctuations of the microorganisms in a vineyard soil under semi-arid conditions. Soil Tillage Res 126:119-126. https://doi.org/10.1016/j.still.2012.09.007

Lorito M, Farkas V, Rebuffat S, Bodo B, Kubicek CP (1996) Cell wall synthesis is a major target of mycoparasitic antagonism by Trichoderma harzianum. J Bacteriol 178:6382-6385. https://doi.org/10.1128/jb.178.21.63826385.1996

Lucini L, Rouphael Y, Cardarelli M, Canaguier R, Kumar P, Colla G (2015) The effect of a plant-derived biostimulant on metabolic profiling and crop performance of lettuce grown under saline conditions. Sci Hortic 182:124-133. https://doi.org/10.1016/j.scienta.2014.11.022

Lupwayi NZ, Rice WA, Clayton GW (1998) Soil microbial diversity and community structure under wheat as influenced by tillage and crop rotation. Soil Biol Biochem 30:1733-1741. https://doi.org/10.1016/S0038-0717(98) 00025-X

Luziatelli F, Ficca A, Colla G, Svecova E, Ruzzi M (2016) Effects of a protein hydrolysate-based biostimulant and two micronutrient based fertilizers on plant growth and epiphytic bacterial population of lettuce. Acta Hortic 1148:43-48. https://doi.org/10.17660/ActaHortic.2016. 1148.5 
Marfà O, Cáceres R, Polo J, Ródenas J (2009) Animal protein hydrolysate as a biostimulant for transplanted strawberry plants subjected to cold stress. Acta Hortic 842:315-318. https://doi.org/10.17660/ActaHortic.2009.842.57

Marjanska-Cichon B, Sapieha-Waszkiewicz A (2011) Efficacy of garlic extracts used to control of grey mould in strawberry. Prog Plant Prot 51:413-420

Massoud MA, Saad ASA, Soliman EA (2012) Antifungal activity of some essential oils applied as fumigants against two stored grains fungi. J Adv Agric Res (Fac Agric Saba Basha) 17:296-306

Matsubayashi Y, Sakagami Y (2006) Peptide hormones in plants. Annu Rev Plant Biol 57:649-674. https://doi.org/ 10.1146/annurev.arplant.56.032604.144204

McEldowney J (2018) Organic farming legislation revision of regulation on organic production and labelling of organic products. CAP reform post-2020 - Setting the scene. Eur Parliam Res Serv 1-11

Meszka B, Bielenin A (2010) Polyversum - a new biological product against strawberry grey mould. The polish phytopathological society. Phytopath Polonica 58:13-19

Miransari M (2011) Arbuscular mycorrhizal fungi and nitrogen uptake. Arch Microbiol 193:77-81. https://doi.org/10. 1007/s00203-010-0657-6

Monte E (2001) Understanding Trichoderma: between biotechnology and microbial ecology. Int Microbiol 4:4-7. https://doi.org/10.1007/s101230100001

Mounir R, Durieux A, Bodo E, Allard C, Simon JP, Achbani EH, El-Jaafari S, Douira A, Jijakli MH (2007) Production, formulation and antagonistic activity of the biocontrol likeyeast Aureobasidium pullulans against Penicillium expansum. Biotechnol Lett 29:553-559. https://doi.org/10. 1007/s10529-006-9269-2

Nardi S, Pizzeghello D, Muscolo A, Vianello A (2002) Physiological effects of humic substances on higher plants. Soil Biol Biochem 34:1527-1536. https://doi.org/10.1016/ S0038-0717(02)00174-8

Oszust K, Pawlik A, Janusz G, Ziemiński K, Cyran M, Siczek A, Gryta A, Bilinska-Wielgus N, Frac M (2017a) Characterization and influence of a multi-enzymatic biopreparation for biogas yield enhancement. BioResources 12:6187-6206. https://doi.org/10.15376/biores.12.3.61876206

Oszust K, Pawlik A, Siczek A, Janusz G, Gryta A, BilińskaWielgus N, Frac M (2017b) Efficient cellulases production by Trichoderma atroviride G79/11 in submerged culture based on soy flour-cellulose-lactose. BioResources 12:8468-8489. https://doi.org/10.15376/biores.12.4.84688489

Ozbay N, Newman SE (2004) Biological control with Trichoderma spp. with emphasis on T. harzianum. Pak J Biol Sci 7:478-484. https://doi.org/10.3923/pjbs.2004.478.484

Pačuta V, Rašovský M, Černý I, Michalska-Klimczak B, Wyszynski Z, Lesniewska J, Buday M (2018) Influence of weather conditions, variety and sea algae-based biopreparations on root yield, sugar content and polarized sugar yield of sugar beet. List Cukrov a Řepařské 11:368-371

Panek J, Frac M (2018) Development of a qPCR assay for the detection of heat-resistant Talaromyces flavus. Int J Food Microbiol 270:44-51. https://doi.org/10.1016/j. ijfoodmicro.2018.02.010
Papavizas GC (1985) Trichoderma and Gliocladium: biology, ecology, and potential for biocontrol. Annu Rev Phytopathol 23:23-54. https://doi.org/10.1146/annurev.py.23. 090185.000323

Parekh J, Jadeja D, Chanda S (2004) Efficacy of aqueous and methanol extracts of some medicinal plants for potential antibacterial activity. Turk J Biol 29:203-210

Park S, Kim KS, Kang D, Yoon H, Sung K (2013) Effects of humic acid on heavy metal uptake by herbaceous plants in soils simultaneously contaminated by petroleum hydrocarbons. Environ Earth Sci 68:2375-2384. https://doi.org/ 10.1007/s12665-012-1920-8

Patkowska E (2006) Effectiveness of grapefruit extract and Pythium oligandrum in the control of bean and peas pathogens. J Plant Prot Res 46:15-28

Picard K, Tirilly Y, Benhamou N (2000) Cytological effects of cellulases in the parasitism of Phytophthora parasitica by Pythium oligandrum. Appl Environ Microbiol 66:4305-4314. https://doi.org/10.1128/AEM.66.10.43054314.2000

Pierson LS, Pierson EA (2010) Metabolism and function of phenazines in bacteria: impacts on the behavior of bacteria in the environment and biotechnological processes. Appl Microbiol Biotechnol 86:1659-1670. https://doi.org/10. 1007/s00253-010-2509-3

Piotrowski W, Sas-Paszt L, Grzyb ZS (2015) Effect of fertilization in organic nursery for later growth and fruiting of apple trees in the orchard. J Life Sci 9:159-165. https://doi. org/10.17265/1934-7391/2015.04.003

Ponisio LC, M'gonigle LK, Mace KC, Palomino J, De Valpine P, Kremen C (2015) Diversification practices reduce organic to conventional yield gap. Proc R Soc B Biol Sci. https://doi.org/10.1098/rspb.2014.1396

Prokkola S, Kivijärvi P (2007) Effect of biological sprays on the incidence of grey mould, fruit yield and fruit quality in organic strawberry production. Agric Food Sci 16:25-33. https://doi.org/10.2137/145960607781635886

Proksa B (2010) Talaromyces flavus and its metabolites. Chem Pap 64:696-714. https://doi.org/10.2478/s11696-0100073-z

Rahman M, Mukta JA, Sabir AA, Gupta DR, Mohi-Ud-Din M, Hasanuzzaman M, Miah MG, Rahman M, Islam MT (2018) Chitosan biopolymer promotes yield and stimulates accumulation of antioxidants in strawberry fruit. PLoS ONE 13:1-14. https://doi.org/10.1371/journal.pone. 0203769

Reddy MVB, Belkacemi K, Corcuff R, Arul J (2000) Effect of pre-harvest chitosan sprays on post-harvest infection by Botrytis cinerea and quality of strawberry fruit. Control 20:39-51. https://doi.org/10.1016/S0925-5214(00)001083

Reis JA, Paula AT, Casarotti SN, Penna ALB (2012) Lactic acid bacteria antimicrobial compounds: characteristics and applications. Food Eng Rev 4:124-140. https://doi.org/10. 1007/s12393-012-9051-2

Roco A, Pérez LM (2001) In vitro biocontrol activity of Trichoderma harzianum on Alternaria alternata in the presence of growth regulators. Electron J Biotechnol 4:68-73. https://doi.org/10.2225/vol4-issue2-fulltext-1

Rouphael Y, Franken P, Schneider C, Schwarz D, Giovannetti M, Agnolucci M, De Pascale S, Bonini P, Colla G (2015) 
Arbuscular mycorrhizal fungi act as biostimulants in horticultural crops. Sci Hortic 196:91-108. https://doi.org/10. 1016/j.scienta.2015.09.002

Rouphael Y, Cardarelli M, Bonini P, Colla G (2017) Synergistic action of a microbial-based biostimulant and a plant derived-protein hydrolysate enhances lettuce tolerance to alkalinity and salinity. Front Plant Sci 8:1-12. https://doi. org/10.3389/fpls.2017.00131

Rubin RL, van Groenigen KJ, Hungate BA (2017) Plant growth promoting rhizobacteria are more effective under drought: a meta-analysis. Plant Soil 416(1-2):309-323. https://doi. org/10.1007/s11104-017-3199-8

Ruzzi M, Aroca R (2015) Plant growth-promoting rhizobacteria act as biostimulants in horticulture. Sci Hortic 196:124-134. https://doi.org/10.1016/j.scienta.2015.08. 042

Sah SK, Reddy KR, Li J (2016) Abscisic acid and abiotic stress tolerance in crop plants. Front Plant Sci 7:1-26. https://doi. org/10.3389/fpls.2016.00571

Saia S, Rappa V, Ruisi P, Abenavoli MR, Sunseri F, Giambalvo D, Frenda AS, Martinelli F (2015) Soil inoculation with symbiotic microorganisms promotes plant growth and nutrient transporter genes expression in durum wheat. Front Plant Sci 6:1-10. https://doi.org/10.3389/fpls.2015. 00815

Salie F, Eagles PFK, Leng HMJ (1996) Preliminary antimicrobial screening of four South African Asteraceae species. J Ethnopharmacol 52:27-33. https://doi.org/10.1016/03788741(96)01381-5

Satyaprakash M, Nikitha T, Redi EUB, Sadhana B, Vani SS (2017) Phosphorous and phosphate solubilising bacteria and their role in plant nutrition. Int J Curr Microbiol Appl Sci 6:2133-2144. https://doi.org/10.20546/ijcmas.2017. 604.251

Schaafsma G (2009) Safety of protein hydrolysates, fractions thereof and bioactive peptides in human nutrition. Eur $\mathrm{J}$ Clin Nutr 63:1161-1168. https://doi.org/10.1038/ejen. 2009.56

Schiavon M, Ertani A, Nardi S (2008) Effects of an alfalfa protein hydrolysate on the gene expression and activity of enzymes of the tricarboxylic acid (TCA) cycle and nitrogen metabolism in Zea mays L. J Agric Food Chem 56:11800-11808. https://doi.org/10.1021/jf802362g

Singh SP, Ekanem E, Wakefield T, Comer S (2003) Emerging importance of bio-based products and bio-energy in the U.S. economy: information dissemination and training of students. Int Food Agribus Manag Rev 5:1-15

Sivan A (1989) The possible role of competition between Trichoderma harzianum and Fusarium oxysporum on rhizosphere colonization. Phytopathology 79:198-203. https:// doi.org/10.1094/Phyto-79-198

Slusarenko AJ, Patel A, Portz D (2008) Control of plant diseases by natural products: allicin from garlic as a case study. Sustain Dis Manag Eur Context. https://doi.org/10.1007/ 978-1-4020-8780-6_10

Stewart LI, Hamel C, Hogue R, Moutoglis P (2005) Response of strawberry to inoculation with arbuscular mycorrhizal fungi under very high soil phosphorus conditions. Mycorrhiza 15:612-619. https://doi.org/10.1007/s00572-0050003-z
Sylla J, Alsanius B, Krüger E, Reineke A, Bischoff-Schaefer M, Wohanka W (2013) Introduction of Aureobasidium pullulans to the phyllosphere of organically grown strawberries with focus on its establishment and interactions with the resident microbiome. Agronomy 3:704-731. https:// doi.org/10.3390/agronomy3040704

Szekeres A, Kredics L, Antal Z, Kevei F, Manczinger L (2004) Isolation and characterization of protease overproducing mutants of Trichoderma harzianum. FEMS Microbiol Lett 233:215-222. https://doi.org/10.1016/j.femsle.2004.02. 012

Szmagara M (2008) Possibilities of growth and development suppression of Topospora myrtilli (Feltg.) Boerema on artificial media and stems of highbush blueberry (Vaccinium corymbosum L.). Acta Sci Pol Hortorum Cultus 7:103-111

Tiwari RKS, Das K, Shrivastava DK (2012) In vitro and in vivo efficacy of organic solvent based extracts of some ethnomedicinal plant species against Xanthomonas oryzae: causal agent of bacterial leaf blight of rice. In: Gupta V, Singh G, Singh S, Kaul A (eds) Medicinal plants: phytochemistry, pharmacology and therapeutics. Daya Publishing House, Daryaganj, pp 341-358

Trewavas A (2001) Urban myths of organic farming. Nature 410:409-410. https://doi.org/10.1038/35068639

Tronsmo A, Dennis C (1977) The use of Trichoderma species to control strawberry fruit rots. Neth J PIant Path 83:449-455. https://doi.org/10.1007/BF03041462

Tuomisto HL, Hodge ID, Riordan P, Macdonald DW (2012) Does organic farming reduce environmental impacts?-a meta-analysis of European research. J Environ Manage 112:309-320. https://doi.org/10.1016/j.jenvman.2012.08. 018

Ugarte RA, Sharp G, Moore B (2006) Changes in the brown seaweed Ascophyllum nodosum (L.) Le Jol. plant morphology and biomass produced by cutter rake harvests in southern New Brunswick, Canada. J Appl Phycol 18:351-359. https://doi.org/10.1007/s10811-006-9044-8

Urban L, Wagner A, Struszczyk H (2004) Effect of treatment with chitosol 1 on fusariosis of tomato. Latv J Agron 1:153-154

Vernieri P, Borghesi E, Tognoni F, Serra G, Ferrante A, Piaggesi A (2006) Use of biostimulants for reducing nutrient solution concentration in floating system. Acta Hortic 718:477-484. https://doi.org/10.17660/ActaHortic.2006. 718.55

Vukicevich E, Lowery T, Bowen P, Úrbez-Torres JR, Hart M (2016) Cover crops to increase soil microbial diversity and mitigate decline in perennial agriculture. A review. Agron Sustain Dev 36:48. https://doi.org/10.1007/s13593-0160385-7

Wagner A, Hetman B (2016) Effect of some biopreparations on health status of strawberry (Fragaria ananassa Duch.). J Agric Sci Technol B 6:295-302. https://doi.org/10. 17265/2161-6264/2016.05.002

Wally OSD, Critchley AT, Hiltz D, Craigie JS, Han X, Zaharia LI, Abrams SR, Prithiviraj B (2013) Regulation of phytohormone biosynthesis and accumulation in arabidopsis following treatment with commercial extract from the marine macroalga Ascophyllum nodosum. J Plant Growth 
Regul 32:324-339. https://doi.org/10.1007/s00344-0129301-9

Wang J, Li J, Cao J, Jiang W (2010) Antifungal activities of neem (Azadirachta indica) seed kernel extracts on postharvest diseases in fruits. Afr $\mathrm{J}$ Microb Res 4(11):1100-1104

Woo SL, Ruocco M, Vinale F, Nigro M, Marra R, Lombardi N, Pascale A, Lanzuise S, Manganiello G, Lorito M (2014) Trichoderma-based products and their widespread use in agriculture. Open Mycol J 8:71-126. https://doi.org/10. 2174/1874437001408010071

Xu WT, Huang KL, Guo F, Qu W, Yang JJ, Liang ZH, Luo YB (2007) Postharvest grapefruit seed extract and chitosan treatments of table grapes to control Botrytis cinerea. Postharvest Biol Technol 46:86-94. https://doi.org/10. 1016/j.postharvbio.2007.03.019

Yang X, Zhang S, Tian Y, Guo W, Wang J (2013) The influence of humic acids on the accumulation of lead $(\mathrm{Pb})$ and cadmium $(\mathrm{Cd})$ in tabacco leaves grown in different soils. J Soil Sci Plant Nutr 13:43-53. https://doi.org/10.4067/S071895162013005000005

Yedidia I, Benhamou N, Chet I (1999) Induction of defense responses in cucumber plants (Cucumis sativus L.) by the biocontrol agent Trichoderma harzianum. Appl Environ Microbiol 65:1061-1070. https://doi.org/10.1007/s00410001-0323-8

Yedidia I, Benhamou N, Kapulnik Y, Chet I (2000) Induction and accumulation of PR proteins activityduring early stages of root colonizationby the mycoparasite
Trichoderma harzianum strain T-203. Plant Physiol Biochem 38(11):863-873. https://doi.org/10.1016/S09819428(00)01198-0

Youssef SMS, Metwally AAFHA (2014) Influence of foliar spraying of seaweed extract on growth, yield and quality of strawberry plants. J App Sci Res 10:88-94

Zardak SG, Dehnavi MM, Salehi A, Gholamhoseini M (2018) Effects of using arbuscular mycorrhizal fungi to alleviate drought stress on the physiological traits and essential oil yield of fennel. Rhizosphere 6:31-38. https://doi.org/10. 1016/j.rhisph.2018.02.001

Zhang X, Wang K, Ervin EH (2010) Optimizing dosages of seaweed extract-based cytokinins and zeatin riboside for improving creeping bentgrass heat tolerance. Crop Sci 50:316-320. https://doi.org/10.2135/cropsci2009.02.0090

Zhao X, Nechols JR, Williams KA, Wang W, Carey EE (2009) Comparison of phenolic acids in organically and conventionally grown pac choi (Brassica rapa $\mathrm{L}$. chinensis). J Sci Food Agric 89:940-946. https://doi.org/10.1002/jsfa.3534

Znini M, Cristofari G, Majidi L, El Harrak A, Paolini J, Costa J (2013) In vitro antifungal activity and chemical composition of Warionia saharae essential oil against 3 apple phytopathogenic fungi. Food Sci Biotechnol 22:113-119. https://doi.org/10.1007/s10068-013-0056-2

Publisher's Note Springer Nature remains neutral with regard to jurisdictional claims in published maps and institutional affiliations. 